\title{
Commensal association of Corbula gibba (Bivalvia) and a sub-conical boring
}

\author{
JAN KRESTEN NIELSEN
}

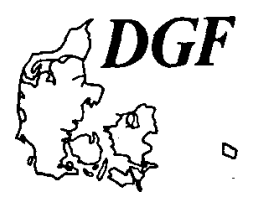

\begin{abstract}
Nielsen, J. K.: Commensal association of Corbula gibba (Bivalvia) and a subconical boring. Bulletin of the Geological Society of Denmark, Vol. 45, pp. 135138. Copenhagen, 1999-01-30. https://doi.org/10.37570/bgsd-1998-45-15
\end{abstract}

An examination of fossil and Recent right valves of the infaunal, suspensionfeeding Corbula gibba (Olivi, 1792) revealed the presence of a slender, subconical, unbranched boring. The boring is interpreted as the work of a commensal organism, possible a parasite. Stratigraphic range is from Eocene to Recent.

Key words: Corbulidae, Trypanites, Conchifora, Cenozoic, commensalism, amensalism.

Jan Kresten Nielsen, Geological Museum, University of Copenhagen, Øster Voldgade 5-7, DK-1350 Copenhagen K. 10 july 1998.

In his monograph, Sorgenfrei (1958) described marine gastropods, bivalves and scaphopods collected from the Middle Miocene Amum Formation, Denmark. In shells of Corbula gibba (Olivi, 1792) he observed what he termed a "marginal pore". Sorgenfrei (1958) had no suggestion for the purpose of the "pore". Except for Sorgenfrei (1958), apparently, the "pore" has not been paid any attention. An interpretation is proposed in the present paper.

\section{Description}

The "pore", which is situated at the posterior margin of the right valve, is located along the boundary between the external and internal shell layers (prismatic and lamellar, respectively, according to Strachimirov 1972). The "pore" has a slender, sub-conical, slightly curved, unbranched shape and a single aperture to the external surface of the shell. The distal end is tapered. The margin is smooth (see Sorgenfrei 1958: 131, Pl. 23: 69a-b, d-f) (Figs 1-2).

\section{Origin}

The "pore" has no connection to the internal cavity of the bivalve and consequently there was no connection to its soft parts. The aperture is situated in the external surface of the shell and "pore" cross-cuts the shell layers. Thus, the "pore" is interpreted here as a boring. Müller (1956) argued for the same interpretation of identical borings. They occur in hard substrates, such as shells (Bromley 1972).

The "pores" in Recent specimens of $C$. gibba may be filled with a gelatinous mass (Sorgenfrei 1958). This mass could represent the decaying tracemaker. According to Müller (1956) and Bromley (1972) various animals, for example annelids, are known to make borings similar to the one in C. gibba.

\section{Ichnotaxonomy}

The boring in C. gibba resembles ichnotaxa of Trypanites Mägdefrau, 1932, and partim Conchifora Müller, 1968. Bromley \& D’Alessandro (1987: 403) diagnosed Trypanites as containing "single-entrance, cylindrical or sub-cylindrical, unbranched borings in lithic substrates, having circular cross-section throughout length. The axes of the borings may be straight, curved or irregular". Following this diagnosis the boring present in Corbula gibba cannot be considered a Trypanites.

The boring in C. gibba resembles Conchifora zylindriformis var. palisadiformis Müller, 1968, which was described as "cast of straight to moderately curved, conical, unbranched boring with a single aperture and with blunt-rounded or tapered end in shells of brachiopods" (translated from Müller 1968: 71). Originally the polymorphic Conchifora was described as including both unbranched and branched borings (see Müller 1968). A taxonomic revision involving type material is badly needed. According to Bromley \& D'Alessandro (1987), C. zylindriformis var. clavi- 


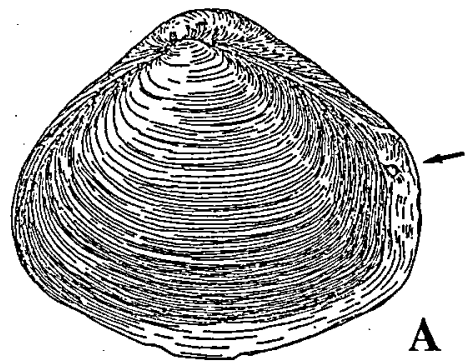

A

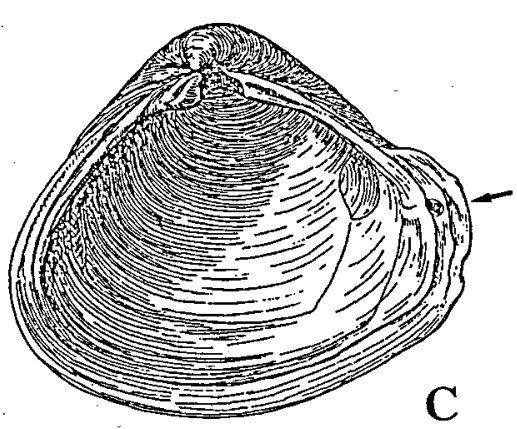

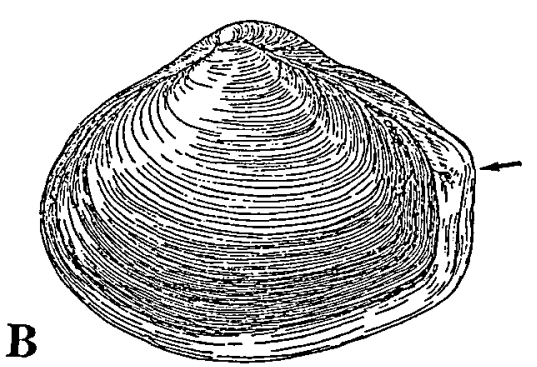

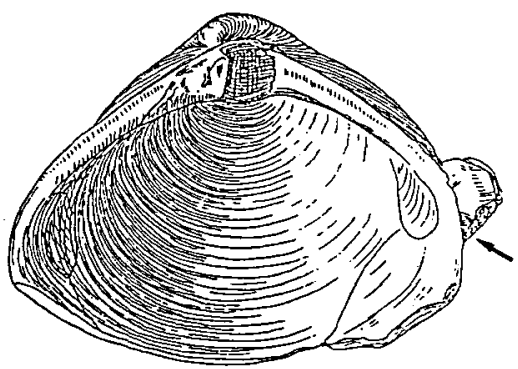

D

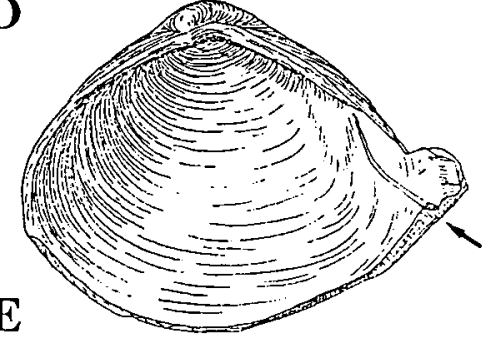

Fig. 1. A, B, articulated valves (length about $4 \mathrm{~mm}$ ) of Corbula gibba. The boring is situated at the posterior margin of the right valve (arrow). C, disarticulated right valve (length 4.27 $\mathrm{mm}$ ) with a boring. D, a disarticulated right valve (length $4.54 \mathrm{~mm}$ ) with attached internal shell layer. $\mathrm{E}$, the same valve (length $3.65 \mathrm{~mm}$ ) with internal shell layer removed. All drawings adopted from Sorgenfrei (1958). formis Müller, 1968 is a junior synonym for T. fimbriatus (Stephenson, 1952). However, C. Plewes (pers. com.) suggests that partim Conchifora should be transferred to Palaeosabella Clarke, 1921. Based on description and illustrations by Müller (1968), T. weisei Mägdefrau, 1932 and C. zylindriformis var. zylindriformis Müller, 1968 seem to be identical. As the latter is holotype for Conchifora igen., Conchifora may have to be abandoned. Therefore, pending a taxonomic revision of this group of borings, the present structure may remain nameless for the time being.

\section{Stratigraphic range}

Sorgenfrei (1958) mentioned that a identical "pore" exists in Eocene (South Carolina to Rio Grande River; Belgium), Miocene (Jamaica) and Recent (Senegal; Shetland Isles, British Isles; Australia) shells belonging to the Corbulidae. I have examined the following samples of Corbula gibba housed in the Zoological Museum (ZM), the Geological Institute (GI), and the Geological Museum (GM), University of Copenhagen, Denmark:
Recent (dry samples):

ZM, Nykøbing, Mors, Denmark (Fig. 2). ZM, Skagens Fyrtårn: NW 1/2 N, $14 \mathrm{~km} \mathrm{1.,} 32 \mathrm{~m}$ depth, pure silt, Kattegat, 27-8-1885. Legit: "Hauch" St. 268. Det. C. G. Joh. Petersen. Journ. M.11/8-1887. ZM, Vinduespollen, Bergen, Norway, 17-9-1901. Legit: K. T. A. Jensen. ZM, loc. $3 \mathrm{~km} \mathrm{l}$. N to E of Vyl Fyrskib, North Sea, 24 m depth, 29-9-1904. Legit: “Thor" St. 255.

Post-glacial (Holocene):

GM 1970.1525, Dosinia stratum, Korsholm, Denmark. GM 1970.1527, southern coast of Øland, Sweden. GM 1970.1528, Kolind Sund, Denmark.

Eemian interglacial (Pleistocene):

GM sample no. 95001, loc. 001, Koleska, Vaga (Sev. Dvina), Russia (collection of S. Funder).

Pleistocene:

GI samples no. 98-565, 98-605, 98-606, Lindos Bay clay, coastal outcrop $600 \mathrm{~m} \mathrm{SW}$ of Thermes Kalitheas, NE Rhodes, Greece (collection of JKN).

Pliocene/Pleistocene:

GI sample no. 79-209, at transition from Kritika For- 


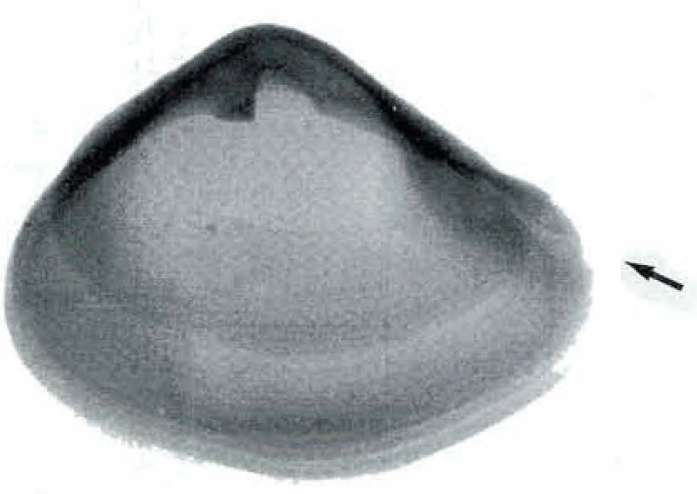

A

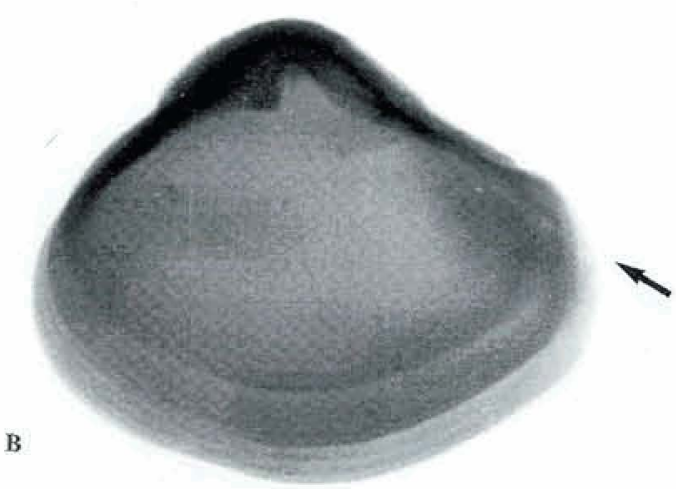

Fig. 2. A, B, x-ray positives of disarticulated right valves of Corbula gibba (Recent, Nykøbing, Mors, Denmark). Note the sub-conical shape of the boring in each valve. Scale $1 \mathrm{~mm}$. Photographic work by J. Aagaard (University of Copenhagen).

mation to Rhodes Formation, Monte Smith, N Rhodes, Greece (collection of M. Hallquist and T. Hansen). GI sample no. 106-801, Kritika Formation, Monte Smith, N Rhodes, Greece (collection of M. Hallquist and T. Hansen).

\section{Pliocene:}

Facies "grey clays", Olona Valley, Varese province, NW Italy (see Brambilla \& Lualdi 1988: Pl. 10: 6b).

Many right valves (length more than $3 \mathrm{~mm}$ ) in these samples contain a boring aperture. The rest of the boring is covered by the internal shell layer and therefore is not visible. The boring aperture and its position are similar to that described by Sorgenfrei (1958) (Fig. 1A-C).

The sample from near Vyl Fyrskib, North Sea, consists mostly of disarticulated valves of $C$. gibba. There are 548 disarticulated right valves. The main part, 512 valves, contains a single specimen of the boring. Nineteen valves contain both the boring and Oichnus paraboloides Bromley, 1981. The position of the two borings seems not to be related. Four valves contain only $O$. paraboloides. Thirty-two valves do not contain any of these borings.

In summary, the boring seems to have a wide geographic and stratigraphic distribution. Locally the boring may be abundant, indicating some ecological control.

\section{Ethology}

Recent specimens of $C$. gibba are suspension feeders and belong to the infauna in marine environments. They are oriented within the substrate with their posterior end upward, having short siphons, a long slender foot and a long byssal thread. The latter indicates a sedentary way of living. If the animal is forcibly disturbed it changes position by burrowing very slowly (Yonge 1946). The bivalve seems not to have had any benefit from the presence of the boring organism, which used the shells for protection. In ethological terms the boring can be classified as a domichnion (see Bromley 1994: Tables 5.1-5.2). The close position of the boring aperture to the posterior end of the bivalve suggests that the occupant was a suspensionfeeder which exploited the suspended nutrients transported by water currents created by the bivalve. Thus, the boring probably was made by a commensal organism, possible a parasite (see Voigt 1965; Müller 1968: 91; Hertweck 1971).

It is remarkable that there is never more than one boring in each right valve of $C$. gibba. This invites an explanation such as amensalism, restriction of nutrients or substrate. The presence of a boring organism primarily requires exposed lithic substrate and current-borne nutrients (e.g., Müller 1968; Hertweck 1971). In the case of Cardium edule, large numbers of Polydora ciliata (Johnston) may colonize the posterior end of the valves where they are just exposed at the sea floor (Hertweck 1971).

C. gibba is able to push its foot out through the inhalant siphon to grope on the surrounding substrate (Yonge 1946). This may have prohibited the settlement of a second boring organism, but it does not explain the presence of the first boring organism.

Alternatively, the first boring organism may have prevented the settlement of other boring organisms, e.g., by swallowing them. It would have prevented competition on nutrients carried with currents produced by the bivalve. 


\section{Conclusion}

Examination of right valves of $C$. gibba revealed that: (1) a slender, sub-conical, unbranched boring may be present, (2) the boring is nameless for the time being, (3) its tracemaker was a commensal organism, possible a parasite, and (4) stratigraphic range of the boring is from Eocene to Recent.

Living specimens of $C$. gibba, with preserved soft parts, exist. It is recommendable that these should be studied to conform the boring and its biogenic origin.

\section{Dansk sammendrag}

Corbula gibba (Olivi, 1792) er en infaunal, suspensionsædende musling. I dens højre skal kan der forekomme en slank, sub-konisk, ugrenet boring. Denne er observeret $i$ eocæne til recente skaller. Boringen tolkes som dannet af en kommensal organisme, muligvis en parasit.

\section{Acknowledgements}

The Geological Survey of Denmark and Greenland (GEUS) gave permission to republish drawings from Sorgenfrei (1958) (The permission do not restrict the use of this material by others authorised by GEUS). Svend Funder and G. Høpner Petersen are thanked for providing access to the collections of the Geological and Zoological Museums of Copenhagen, respectively. Maria Hallquist and Thomas Hansen (Copenhagen) provided Pliocene/Pleistocene material from Monte Smith. Elsebeth Thomsen (Tromsø), Markus Bertling (Münster) and Richard G. Bromley (Copenhagen) kindly read and criticized an early draft of the manuscript.

\section{References}

Brambilla, L. \& Lualdi, A. 1988: Il Pliocene della Valle Olona (Varese, Italia NW) nelle Collezioni Sordelli 187479, Parona 1883 e Nangeroni 1928. Atti della Società italiana di Scienze naturali e del Museo civico di Storia naturale di Milano 129, 5-32.

Bromley, R. G. 1972: On some ichnotaxa in hard substrates, with a redefinition of Trypanites Mägdefrau. Paläontologische Zeitschrift 46, 93-98.

Bromley, R. G. 1994: The palaeoecology of bioerosion. In Donovan, S. K. (ed.) The palaeobiology of trace fossils, 134-154. Chichester: John Wiley \& Sons.

Bromley, R. G. \& D'Alessandro, A. 1987: Bioerosion of the Plio-Pleistocene transgression of southern Italy. Rivista Italiana di Paleontologia e Stratigrafia 93, 379442.

Hertweck, G. 1971: Polydora ciliata auf lebenden Herzmuscheln. Natur und Museum 101, 458-466.

Müller, A. H. 1956: Weitere Beiträge zur Ichnologie,
Stratinomie und Ökologie der germanischen Trias. Geologie 5, 405-423.

Müller, G. 1968: Bohr-Röhren von unbekannten Anneliden und anderen Organismen in unterdevonischen Brachiopodenklappen aus der Eifel und dem Siegerland (Rheinisches Schiefergebirge). 121 pp. Universität zu Köln: Inaugural-Dissertation.

Sorgenfrei, T. 1958: Molluscan assemblages from the marine Middle Miocene of South Jutland and their environments. Danmarks Geologiske Undersøgelse II. Serie, $79,503 \mathrm{pp}$.

Strachimirov, B. 1972: Recherches morphologiques et microstructurales sur la coquille de Corbula (Varicorbula) gibba Olivi du Tortonien et du Tchokrakien en Bulgarie. International Geological Congress 24th session, 7, 41-47.

Voigt, E. 1965: Über parasitische Polychaeten in KreideAustern sowie einige andere in Muschelschalen bohrende Würmer. Paläontologische Zeitschrift 39, 193-211.

Yonge, C. M. 1946: On the habits and adaptations of Aloidis (Corbula) gibba. Journal of the Marine Biological Association of the United Kingdom 26, 358-376. 


\title{
Foraminiferivory revisited: a preliminary investigation of holes in foraminifera
}

\author{
KURT SØREN SVENSSON NIELSEN
}

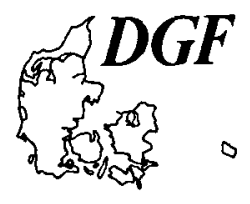

\begin{abstract}
Nielsen, K. S. S.: Foraminiferivory revisited: a preliminary investigation of holes in foraminifera. Bulletin of the Geological Society of Denmark, Vol. 45, pp. 139142. Copenhagen, 1999-01-30.
\end{abstract}

Planktonic and benthonic foraminiferal tests from modern tropical-subtropical marine environments were investigated with regard to bioerosional traces. The traces found on the foraminiferal tests were grouped into 7 different categories. It is suggested that the different traces may be related to different unknown predators of which at least one is planktonic.

Key words: Foraminiferivory, predation, planktonic foraminifera, borings.

K. S. S. Nielsen, Geological Institute, University of Copenhagen, Øster Voldgade 10, DK-1350 Copenhagen K, Denmark. 23 September 1998.

The term foraminiferivory was introduced by Hickman \& Lipps in 1983 to cover the general phenomenon of ingestion of foraminifera. Little is known about the relationship between the predators and the foraminifera in modern communities. The problem is further complicated by the alleged uncertainties as to why foraminifera are eaten (Hickman and Lipps 1983, Walker 1971). Many fish (Daniels \& Lipps 1987, Lipps 1988) and macro-invertebrates are known to ingest foraminifera (Arnold et al. 1985, Berger 1971, Boltoskoy \& Zapata 1980, Brand \& Lipps 1982, Buzas and Carle 1979, Hickman \& Lipps 1983, Langer et al. 1995, Lipps et al. 1974, Mageau et al. 1975, Reyment 1966, Sliter 1971, and Walker 1971). All fish and most of the invertebrates do so incidentally. However, a few invertebrates (gastropods, nematodes and scaphopods) seem to prey selectively on benthonic foraminifera (Langer et al. 1995). Few of these animals leave traces on the foraminiferal tests and most tests are probably destroyed in the process of ingestion. In addition, a few reports exist on predaceous and parasitic foraminifera preying on other benthonic foraminifera (Banner 1971, Baumfalk et al. 1982, Cedhagen 1994, Freiwald \& Schönfeld 1996, Hallock \& Talge 1994, Plewes et al. 1993, Todd 1965, and Vénec-Peyre 1996).

\section{Results}

Holes in foraminiferal tests found in five samples from the Danish deep-sea expedition Galathea (1950-52) and two samples from the Gulf of Aqaba are here interpreted as predation of foraminifera through boring.
Almost all hitherto described examples of foraminiferivory involve either ingestion of or borings in benthonic foraminiferal tests. Based on the morphology of the holes found in the planktonic foraminifera it is possible to establish seven different categories. Group A: Circular to sub-circular holes (Figs 1, 2), Group B: Oval to sub-oval holes (Figs 3, 4), Group $C$ : Pits (Figs 5, 6), Group D: Bite traces (Figs 7, 8), Group E: Circular to oval holes that end in a floor with a minute perforation (Figs 9, 10), Group F: Cupshaped holes (Figs 11, 12), Group G: Star-shaped holes (Figs 13, 14). None of the bored tests exceeds $350 \mu \mathrm{m}$ in size and in tests containing more than one boring the additional borings occur in separate chambers. All hole categories, except for group G, were also found in benthonic foraminifera.

\section{Discussion}

It is assumed that most of the borings are the result of predation. Since the unknown predators seem to be size-selective relative to planktonic foraminifera, it is likely that the primary target for these predators is the cytoplasm in the foraminiferal test. The position of additional borings in separate chambers seems to support this suggestion. Bé \& Spero (1981) described repair processes in planktonic foraminifera when subjected to experimental damage of the test. No such structure has been observed in association with the borings and it is assumed that the foraminifera died from the attack. Since planktonic and benthonic foraminifera inhabit different environments it is most 

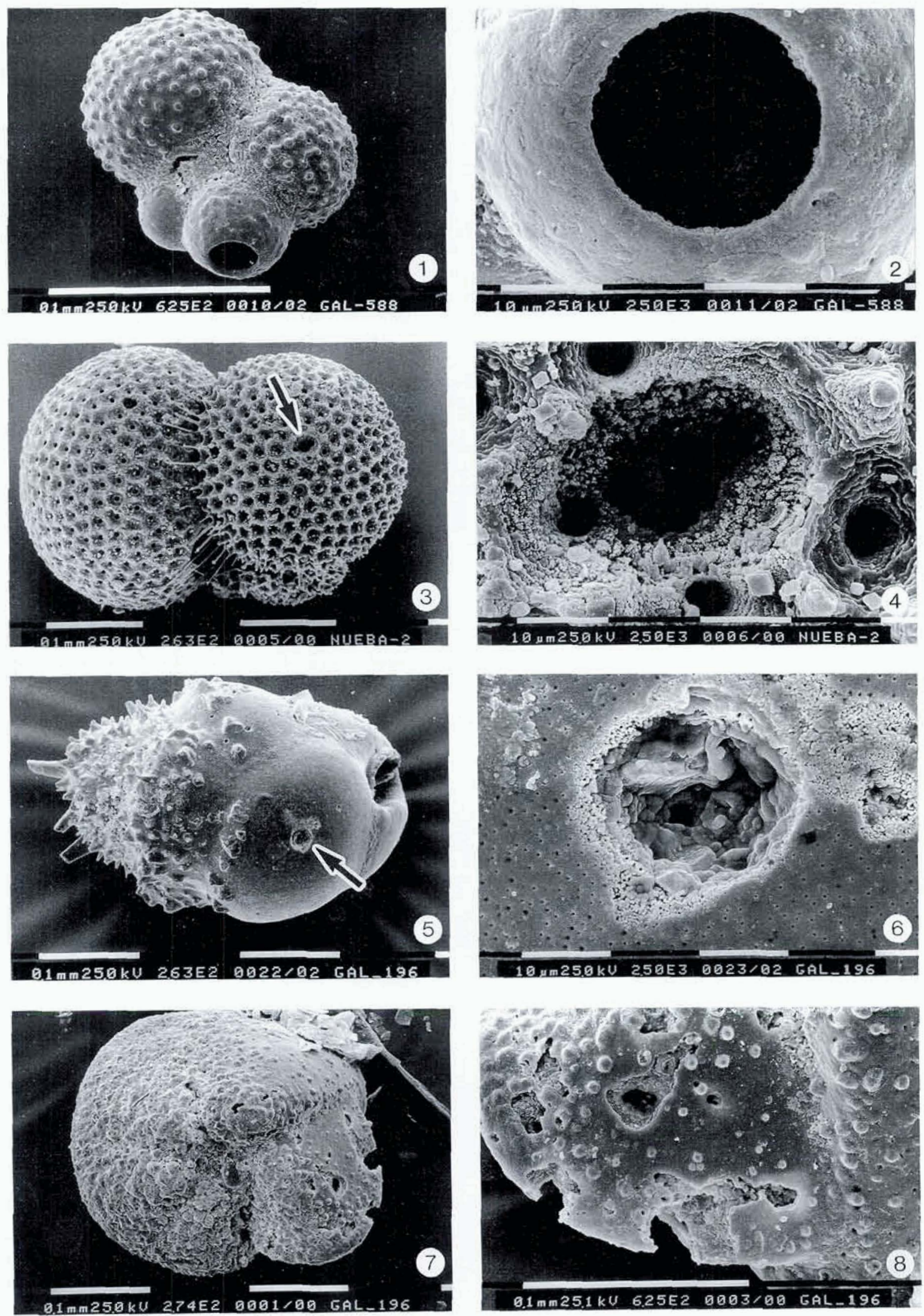

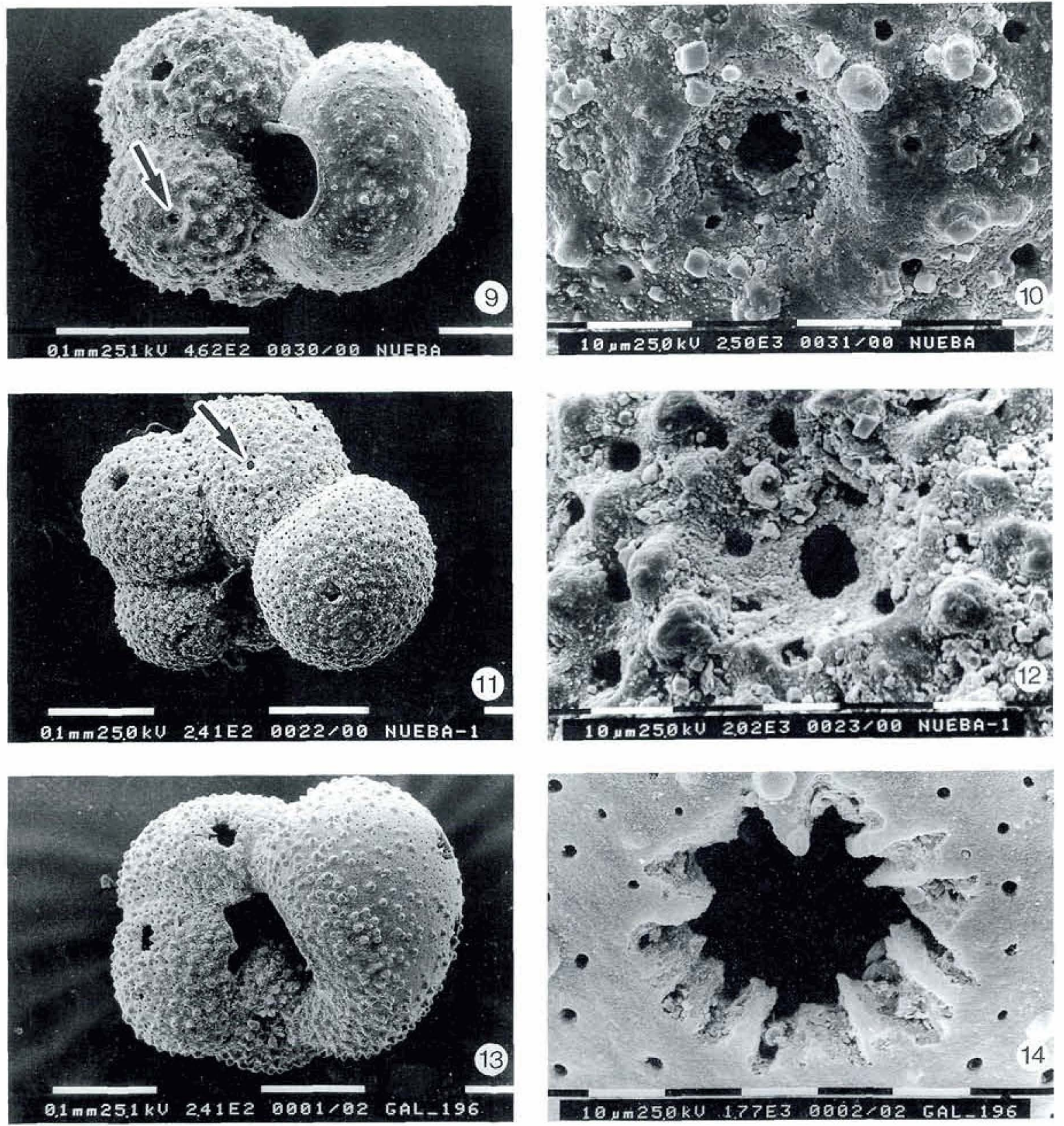

Figs 1-14. General and close-up views (see arrows). 1, 2: Group A. 3, 4: Group B. 5, 6: Group C. 7, 8: Group D. 9, 10: Group E. 11, 12: Group F. 13, 14: Group G. All figures except 5 and 6 are planktonic foraminifera. Scale at bottom of figures.

likely that at least two different predators are involved of which one is planktonic.

\section{Acknowledgements}

The author is indebted to Hans Jørgen Hansen (Copenhagen), who kindly provided the material used in this investigation and for helpful suggestions; Richard G. Bromley and Eckart Håkansson (Copenhagen), for their critical review of the manuscript and Jan Agaard for helping with the pictures. 


\section{Dansk sammendrag}

Betegnelsen foraminiferivory blev i 1983 introduceret af Hickman \& Lipps for at dække det generelle fænomen, at nogle marine dyregrupper og fugle fortærer foraminiferer. Tidligere undersøgelser synes at indikere, at foraminiferer ikke har været et primært fødeemne for de fleste af disse dyregrupper. Analyser af maveindholdet fra nogle arter af rovsnegle og søtænder viser dog, at kalkskallede bentoniske foraminiferer udgør en betragtelig del af disse makroinvertebraters diæt.

For størstedelen af de foraminiferer, som bliver spist, gælder det formodentlig, at deres kalkskaller enten bliver knust af dyrets munddele, bliver opløst under fordøjelsesprocessen eller passerer igennem dyrenes fordøjelsessystem uden at der efterlades spor på skallen, der vidner om, at foraminiferen er blevet fortæret.

Prøver fra den danske Galatheaekspedition (19501952) og fra Aqaba bugten blev undersøgt med henblik på at påvise spor på kalkskallerne efter prædation på nulevende arter af planktoniske foraminiferer. De fundne spor kan morfologisk inddeles i 7 kategorier (A-G). Sporene er her tolket som værende af biogen oprindelse og menes dannet ved prædationsadfærd af et eller flere planktoniske rovdyr.

Hypotesen synes understøttet af den omstændighed, at de ukendte spordannere udvælger planktoniske foraminiferer af en størrelse, der er mindre end $350 \mu \mathrm{m}$, og at hvis der forekommer mere end et spor i skallen, er disse placeret i forbindelse med nye skalkamre.

$\mathrm{Da}$ alle kategorier af spor undtagen gruppe $\mathrm{G}$ også er påvist på kalkskaller af bentoniske foraminiferer er det muligt, at der er mere end to forskellige spordannere $o g$ at en af dem er et planktonisk rovdyr.

\section{References}

Arnold, A. J. d', Escrivan, F. \& Parker, W. C. 1985: Predatory and avoidance responses in foraminifera of the Galapegos hydrothermal mounds. Journal of Foraminiferal Research 15, 38-42.

Banner, F. T. 1971: A new genus of the Planorbulinidae, an endoparasite of another foraminifera. Revista Espasola De Micropaleontologia 3, 113-128.

Baumfalk, Y.A, Fortuin, A. R. \& Mok, R. P. 1982: Talpinella cunicularia n. gen., n. sp., a possible foraminiferal parasite of Late Cretaceous Orbitoides . Journal of Foraminiferal Reseach 12, 185-196.

Bé, A. W. H. \& Spero, H. J. 1981: Shell regeneration and biological recovery of planktonic foraminifera after physical injury induce in laberatory culture. Micropaleontology 27, 305-316.

Berger, W. H. 1971: Planktonic foraminifera: sediment production in an oceanic front. Journal of Foraminiferal Research 1, 95-118.

Boltoskoy, E. \& Zapata, A. 1980: Foraminiferos bentonicos como alimento de otros organismos. Revista Española de Micropaleontologia 12, 191-198.
Brand, T. E \& Lipps, J. H. 1982: Foraminifera in the trophic structure of shallow-water Antartictic marine communities. Journal of Foraminiferal Reseach 12, 96-105.

Buzas, M. A. \& Carle, K. J. 1979: Predators of foraminifera in the Indian River, Florida. Journal of Foraminiferal Research 9, 336-340.

Cedhagen, T. 1994: Taxonomy and biology of Hyrrokkin sarcophaga gen. et sp. n., a parasitic foraminiferan (Rosalinidae). Sarsia 79, 65-82.

Daniels, R. A \& Lipps, J. H. 1978: Predation on foraminifera by antarctic fish. Journal of Foraminiferal Research $8,100-113$.

Freiwald, A. \& Schönfeld, J. 1996: Substrate pitting and boring pattern of Hyrrokkin sarcophaga Cedhagen, 1994 (Foraminiera) in a modern deep-water coral reef mound. Marine Micropaleontology 28, 199-207.

Hallock, P. \& Talge, H. K. 1994: A predatory foraminifera, Floresina Amphiphaga, n. sp., from Florida Keys. Journal of Foraminiferal Research 24, 210-213.

Hickman, C. S. \& Lipps, J. H. 1983: Foraminiferivory: Selective ingestion of foraminifera and test alterations produced by the neogastropod Olivella.. Journal of Foraminiferal Research 13, 108-114.

Langer, M. R., Lipps, J. H. \& Moreno, G. 1995: Predation on foraminifera by the dentaliid deep-sea scaphopod Fissidentalium megathyris. Deep-Sea Resarch 42, 849857.

Lipps, J. H. \& Ronan, T. E. 1974: Predation on foraminifera by the polychaete worm, Diopatra. Jounal of Foraminiferal Research 4, 139-143.

Lipps, J. H. 1988: Predation on foraminifera by coral reef fish. Taphonomic and evolutionary implications. Palaios 3, 315-326.

Mageau, C. N. \& Walker, D. A. 1975: Effects of ingestion of foraminifera by larger invertebrats. First international symposium on benthonic foraminifera of continental margiens. Part A. Ecology and Biology. Maritime Sediments, Special Publications 1, 89-105.

Plewes, C.R, Palmer, T.J. \& Haynes, J. R. 1993: A boring foraminiferan from the Upper Jurassic of England and Northern France. Journal of Micropalaeontology, 12, 8389.

Reyment, R. A. 1966: Preliminary observationer on gastropod predation in the western Niger delta. Palaeogeography, Palaeoclimatology, Palaeoecology 2, 81-102.

Sliter, W. V. 1971: Predation on benthic foraminifera. Journal of Foraminiferal Research 1, 20-28.

Todd, R. 1965: A new Rosalina (foraminifera) parasitic on a bivalve. Deep-Sea Research 12, 831-837.

Vénec-Peyre, M. 1996: Bioeroding foraminifera: a review. Marine Micropaleontology 28, 19-30.

Walker, D. A. 1971: Etching of test surface of benthonic foraminifers due to ingestion by the gastropod Littorina littorea Linne. Canadian Journal of Earth Science 8, 1487-1491. 